\title{
Erzurum Şartlarında Bazı Yem Bezelyesi Hat ve Çeşitlerinin Tohum Verimleri ile Bazı Özelliklerinin Belirlenmesi
}

\author{
Sibel KADIOĞLU \\ Mustafa TAN ${ }^{2 *}$ \\ ${ }^{1}$ Doğu Anadolu Tarımsal Araştırma Enstitüsü, Erzurum \\ ${ }^{2}$ Atatürk Üniversitesi, Ziraat Fakültesi, Tarla Bitkileri Bölümü, Erzurum \\ (*Sorumlu yazar e-mail: mustan @ atauni.edu.tr) \\ DOI: 10.17097/ataunizfd.403323 \\ Geliş Tarihi : 08.03.2018 \\ Kabul Tarihi : 20.04.2018
}

\begin{abstract}
ÖZ: Araștırma Erzurum şartlarında bazı yem bezelyesi hat ve ceșitlerinin kışı geçirme oranı, tohum verimi ve ilgili özelliklerini belirlemek amacıyla planlanmıştır. 8 hat (Hat No: 5, 6, 8, 10, 13, 14, 15 ve 17) ve 5 çeşit (Töre, Özkaynak, Kirazlı, Taşkent ve Ürünlü) 2012-13 ve 2013-14 kışlık ürün yetiştirme sezonunda şansa bağlı tam bloklar deneme deseninde 3 tekrarlamalı olarak incelenmiștir. İki yıllık sonuçlara göre incelenen genotiplerin Erzurum şartlarındaki performanslarında önemli farklılıklar görülmüştür. 15 ve 10 numaralı hat ve Özkaynak çeşidi en yüksek tohum verimine sahip olmuşlardır. Bununla birlikte hasat indeksinde Taşkent, kıșı geçirme oranında ise Özkaynak çeșidi ilk sırayı almıștır.
\end{abstract}

Anahtar kelimeler: Yem bezelyesi, genotip, adaptasyon, tohum verimi

\section{Determination of Seed Yield and Some Characteristics of Some Forage Pea Lines and Varieties in Erzurum Conditions}

\begin{abstract}
The research was planned to determine the winter survival rate, seed yield and related characteristics of some forage pea lines and varieties in Erzurum winter conditions. 8 lines (Line No. 5, 6, 8, 10, 13, 14, 15 and 17) and 5 varieties (Töre, Özkaynak, Kirazlı, Taşkent and Ürünlü) of forage pea were tested in randomized complete blocks design with 3 replications in the 2012-13 and 2013-14 crop seasons. There were significant differences in the performance of the genotypes examined according to the two year results in Erzurum conditions. Line-15, Line-10 and Özkaynak variety have higher seed yield than other genotypes. In addition, Taşkent has the highest harvest index and Özkaynak has the highest winter survival rate in the study.
\end{abstract}

Keywords: Forage pea, genotypes, adaptation, seed yield

\section{GÍRIŞ}

Yem bezelyesi (Pisum sativum ssp. arvense L.) ülkemizde tarımı yaygınlaşan baklagil yem bitkisi türlerinden birisidir. 2017 y1lı verilerine göre 69.595 da alanda yetiştiriciliği yapılmaktadır (TÜİK, 2017). Otu hemen her türlü çiftlik hayvanı için besleyici ve lezzetlidir (Açıkgöz, 2001). Tohumları hem ruminantlar hem de kanatlılar için enerji ve protein kaynağı olarak değerli bir yemdir (Ayaşan, 2010). Tek y1llık olduğu için ekim nöbeti sistemleri içerisinde rahatlıkla yer bulabilmektedir. Atmosfer azotunu toprağa bağladığından ülkemizde yaygın ekilen tahıllar için iyi bir ön bitkidir. $\mathrm{Bu}$ nedenle ekim alanlarının yaygınlaşması hem hayvan besleme de hem de ekim nöbeti sistemlerinin geliştirilmesinde faydalı olacaktır.

Yem bezelyesi Erzurum, Ardahan, Kars, Bayburt ve Erzincan gibi Doğu Anadolu Bölgesi illerinde çok eskiden beri yetiştirilmekte ve külür olarak bilinmektedir (Tosun, 1974; Tan vd., 2011). Diğer bölgelerimize göre yaz dönemi nispeten serin geçen bu yörede yem bezelyesi yetiştiriciliği daha kolay yapılmaktadır. Doğu Anadolu bölgesinde mısır ve soya gibi tane yemlerin yetiştiriciliği hemen hemen hiç yok denecek kadar azdır. Bölgede yağlı tohum küspesi üreten yağ fabrikası ve benzeri tesisler de bulunmamaktadır. $\mathrm{Bu}$ nedenle ruminantların protein ihtiyaçlarının karşılanmasında rasyonlara baklagil tohumlarının katılması (Kaya ve Yalçın, 1999) yaygın olarak uygulanmaktadır. $\mathrm{Bu}$ açıdan yem bezelyesinin Doğu Anadolu bölgesi için ayrı bir önemi vardır. Zaten değerli bir tane yem olan yem bezelyesi Avrupa'da soya ürünlerine sinırlama getirilmesinden sonra kesif yem üretiminde en fazla kullanılan bitkilerden birisi haline gelmiştir (Masoero vd., 2006; Volpelli vd., 2009).

Ülkemizde önemi ve kullanımı her geçen gün biraz daha artan yem bezelyesi ile ilgili çalışmalar da artış göstermektedir. Hemen hemen bütün bölgelerimizde yem bezelyesi adaptasyonu ile ilgili araştırmalar yürütülmektedir. Tekirdağ'da Tekeli ve Ateş (2003), Ankara'da Timurağaoğlu vd. (2004), Konya'da Tamkoç (2007), Diyarbakır'da Sayar (2007), Şanlıurfa'da Çil (2007), İzmir'de Geren ve Alan (2012), Kavut vd. (2016), Erzurum'da Tan vd. (2012 ve 2013) ve Kadığlu (2011), Sivas'ta Karaköy vd. (2016), Bursa'da Uzun vd. (2005 ve 2012) ve Türkiye'nin değişik bölgelerinde Açıkgöz vd. (2007) yem bezelyesi hat veya çeşitlerinde ot ve tohum verimini incelemişlerdir. Yürütülen bu çalışmalar sonucunda ülkemizde çok sayıda yem bezelyesi çeşidi geliştirilmiş ve tescil edilmiştir. Doğu Anadolu Bölgesinde ise hala yerel çeşitlerin yetiştiriciliği devam etmektedir. Yem bezelyesinin en fazla yetiştiriciliğinin yapıldığı bu bölgede yem 
bezelyesi çeşitlerinin geliştirilmesi gerekmektedir. $\mathrm{Bu}$ araştırma; bölgede geliştirilmiş yem bezelyesi hatlarının kışlık şartlarda tohum verim potansiyellerinin belirlenmesi ile ülkemizdeki çeşitlerle karşılaştırılmasını konu almaktadır.

\section{MATERYAL VE METOT}

Araştırma 2012-13 ve 2013-14 kışlık ürün yetiştirme sezonu içerisinde, Erzurum'da Doğu Anadolu Tarımsal Araştırma Enstitüsü (DATAE) Pasinler Deneme İstasyonunda yürütülmüştür. Araştırmada yem bezelyesi (Pisum sativum ssp. arvense L.)'nin DATAE'de geliştirilmiş 8 hattı (Hat No: $5,6,8,10,13,14,15$ ve 17 ) ve ülkemizde tescil edilmiş 5 çeşit (Töre, Özkaynak, Kirazlı, Taşkent ve Ürünlü) ele alınmıştır. Araştırmada kullanılan hatlar Doğu Anadolu ve Karadeniz Bölgesinden toplanmış yerel çeşitlerden seleksiyon ile geliştirilmişlerdir. 13 genotip şansa bağlı tam bloklar deneme deseninde 3 tekrarlamalı olarak incelenmiştir. Ekimde metrekarede 100 bitki olacak şekilde tohum kullanılmış, sıra aralığı $35 \mathrm{~cm}$ (Uzun, 1997; Tan, 2018), parsel ebatları $1.75 \mathrm{~m}$ x $5 \mathrm{~m}$ olarak ayarlanmıştır. Ekimler Eylül ayı içerisinde yapılmış ve çıkışları garantilemek için deneme alanı sulanmıştır. Ayrıca her iki yılda da ot hasadından sonra Temmuz ayı içerisinde bakla dolumu için bir defa sulama yapılmıştır. Ekim sırasında $4 \mathrm{~kg} \mathrm{~N} /$ da ve
$5 \mathrm{~kg} \quad \mathrm{P}_{2} \mathrm{O}_{5} / \mathrm{da}$ dozunda gübre uygulanmıştır (Kadığlu, 2011; Tan, 2018). Kasım ayı içerisinde parsellerde çıkışlar tamamlandıktan sonra orta sıraların birinde bitki sayımı yapılmış, aynı sıra kış sonrası Nisan ayında tekrar sayılarak kışı geçen bitki oranları belirlenmiştir. Tohum hasatları baklaların çoğunluğunun olgunlaştığı devrede yapılmıştır. Hasatta parsellerin başlarından $0.5 \mathrm{~m}$ ve kenarlardan birer sıra atılarak $4.2 \mathrm{~m}^{2}$ lik alan tohum için hasat edilmiştir. Çiçeklenme süresi parsellerde $\% 10$ çiçeklenme tarihi esas alınarak belirlenmiştir. Bitki boyu değerleri çiçeklenme döneminde orta sıralardan seçilen 10 bitkide ölçülmüştür. Elde edilen veriler MSTAT-C istatistik paket programı yardımıyla varyans analizine tabi tutulmuş, önemli bulunan ortalamalar LSD testi ile değerlendirilmiştir.

Erzurum Meteoroloji Bölge Müdürlüğü'nün verilerine göre araştırmanın yürütüldüğü ilk yıl (2012-2013) uzun yıllar ortalamasına göre daha serin ve daha kurak geçmiştir (Çizelge 1). İkinci deneme y1lı ise tam tersine uzun yillar ortalamasından daha sıcak ve daha yağışlı seyretmiştir. Birinci deneme yılında Kasım, Şubat ve Mart ayı sıcaklıkları (-3.8, 14.3 ve $-6.9^{\circ} \mathrm{C}$ ) ikinci yıldan belirgin olarak düşük, yine ilk deneme yılının yă̆ışı Eylül, Ekim, Aralık, Mayıs ve Temmuz aylarında ikinci yıldan düşük; Kasım, Ocak, Şubat ve Nisan aylarında yüksek olmuştur.

Çizelge 1. Erzurum ilinin deneme yılları ile uzun yıllar ortalaması sıcaklık ve yağış değerleri

\begin{tabular}{|c|c|c|c|c|c|c|}
\hline \multirow[t]{2}{*}{ Aylar } & \multicolumn{3}{|c|}{ Sicaklık $\left({ }^{\circ} \mathrm{C}\right)$} & \multicolumn{3}{|c|}{ Yağış (mm) } \\
\hline & $2012-13$ & $2013-14$ & UYO* & $2012-13$ & 2013-14 & UYO \\
\hline Eylül & 13.9 & 15.1 & 14.5 & 16.0 & 72.0 & 22.2 \\
\hline Ekim & 7.5 & 6.6 & 7.9 & 30.0 & 45.5 & 43.7 \\
\hline Kasım & -3.8 & 2.9 & 0.6 & 38.0 & 29.0 & 31.5 \\
\hline Aralık & -11.0 & -13.8 & -5.9 & 27.5 & 43.0 & 21.2 \\
\hline Ocak & -8.8 & -8.7 & -9.4 & 42.0 & 18.0 & 19.9 \\
\hline Şubat & -14.3 & -6.6 & -8.1 & 41.0 & 10.0 & 23.9 \\
\hline Mart & -6.9 & 2.7 & -7.4 & 39.0 & 36.0 & 32.6 \\
\hline Nisan & 7.2 & 7.2 & 5.3 & 45.0 & 21.5 & 52.2 \\
\hline Mayıs & 11.6 & 11.6 & 10.6 & 32.0 & 94.0 & 68.5 \\
\hline Haziran & 16.0 & 15.7 & 14.9 & 26.5 & 27.0 & 47.4 \\
\hline Temmuz & 18.8 & 20.5 & 19.3 & 7.5 & 13.0 & 25.8 \\
\hline Ağustos & 20.4 & 21.5 & 19.3 & 6.0 & 5.4 & 16.3 \\
\hline Top./Ort. & 4.2 & 6.2 & 5.1 & 350.5 & 414.4 & 405.2 \\
\hline
\end{tabular}

UYO: Uzun yıllar ortalaması (1954-2010) 
Deneme alanı toprakları tınlı yapıda olup, hafif alkalin karakterde (pH: 7.64-7.70), tuzsuz (toplam tuz: \%0.07-011) ve orta-yüksek kireçli (kireç: \%2.285.34) topraklardır. Organik madde (\%2.03-2.75) ve fosfor (7.76 $\mathrm{kg} \mathrm{P}_{2} \mathrm{O}_{5} / \mathrm{da}$ ) düzeyi orta olan topraklar, potasyumca (62-126 $\mathrm{kg} \mathrm{K}_{2} \mathrm{O} / \mathrm{da}$ ) zengin seviyededir.

\section{BULGULAR VE TARTIŞMA}

Araştırmada bitki boyu yem bezelyesi genotiplerine göre önemli değişim göstermiş, yıllar ve genotip x yll interaksiyonu önemsiz bulunmuştur (Çizelge 2). Töre çeşidi $97.0 \mathrm{~cm}$ ile en uzun boylu genotip olmuştur. Bunu H-13 (93.7 cm) ve H-14
$(92.3 \mathrm{~cm})$ hatları takip etmişlerdir. En kısa boylu $(56.7 \mathrm{~cm})$ bitkiler ise $\mathrm{H}-17$ hattında ölçülmüştür. Boylanma bitkilerde genetik yapı ve çevre şartlarının etkisi altında ortaya çıkan bir özelliktir. Ekolojik şartlara iyi uyum sağlayan çeşitler daha iyi gelişmekte ve daha uzun boylu olmaktadırlar. $\mathrm{Bu}$ nedenle yapılan çalışmalarda da yem bezelyesi bitki boyunun çeşitlere göre farkl11lklar gösterdiği ortaya konulmuştur. Genotipler farklı bölgelerde farklı sonuçlar verebilmektedir (Bilgili vd., 2010). Kavut vd. (2016) İzmir şartlarında inceledikleri Töre, Taşkent ve Kirazlı çeşitleri arasında Kirazlı'nın daha uzun boylu olduğunu belirlemişlerdir.

Çizelge 2. Yem bezelyesi genotiplerinin bitki boyu ve çiçeklenme süreleri

\begin{tabular}{|c|c|c|c|c|c|c|}
\hline \multirow{2}{*}{ Genotipler } & \multicolumn{3}{|c|}{ Bitki Boyu $(\mathrm{cm})$} & \multicolumn{3}{|c|}{ Çiçeklenme Süresi (gün) } \\
\hline & $2012-13$ & $2013-14$ & Ortalama & $2012-13$ & $2013-14$ & Ortalama \\
\hline Kirazlı & 84.3 & 77.2 & $80.7 \mathrm{AB}$ & 226 & 230 & 228 \\
\hline Özkaynak & 78.9 & 96.8 & $87.8 \mathrm{AB}$ & 228 & 240 & 234 \\
\hline Taşkent & 75.7 & 94.4 & $85.1 \mathrm{AB}$ & 229 & 223 & 226 \\
\hline Töre & 79.3 & 114.7 & $97.0 \mathrm{~A}$ & 228 & 238 & 233 \\
\hline Ürünlü & 84.1 & 70.6 & $77.4 \mathrm{ABC}$ & 225 & 238 & 232 \\
\hline $\mathrm{H}-5$ & 88.1 & 81.7 & $84.9 \mathrm{AB}$ & 225 & 230 & 227 \\
\hline H-6 & 78.5 & 79.6 & $79.1 \mathrm{AB}$ & 220 & 230 & 225 \\
\hline $\mathrm{H}-8$ & 78.8 & 84.7 & $81.8 \mathrm{AB}$ & 220 & 240 & 230 \\
\hline $\mathrm{H}-10$ & 78.7 & 79.9 & $79.3 \mathrm{AB}$ & 219 & 230 & 224 \\
\hline H-13 & 96.7 & 90.7 & $93.7 \mathrm{~A}$ & 222 & 238 & 230 \\
\hline H-14 & 97.1 & 87.6 & $92.3 \mathrm{~A}$ & 217 & 238 & 228 \\
\hline H-15 & 80.2 & 61.7 & $70.9 \mathrm{BC}$ & 226 & 228 & 227 \\
\hline H-17 & 59.3 & 54.1 & $56.7 \mathrm{C}$ & 226 & 230 & 228 \\
\hline Ortalama & 81.5 & 82.6 & 82.1 & 224 & 234 & 229 \\
\hline $\begin{array}{l}\text { Önemlilik } \\
\text { LSD }\end{array}$ & $\begin{array}{c}\text { Genotip** } \\
21.0\end{array}$ & $\begin{array}{l}\text { Y1l } \\
\text { ö.d. }\end{array}$ & $\begin{array}{c}\text { Gx Y } \\
\text { ö.d. }\end{array}$ & $\begin{array}{c}\text { Genotip } \\
\text { ö.d. }\end{array}$ & $\begin{array}{c}\mathrm{Y}_{1} 1^{* *} \\
0.9\end{array}$ & $\begin{array}{c}\text { G x Y } \\
\text { ö.d. }\end{array}$ \\
\hline
\end{tabular}

** 0.01 düzeyinde önemlilik gösterir. Farklı harfle işaretlenmiş ortalamalar istatistiksel olarak birbirinden farklıdır. ö.d.: Önemli değil

$\mathrm{Bu}$ çalışmada yem bezelyesi genotiplerinin çiçeklenmeye ulaşma süreleri 217-240 gün arasında değişmiş ve istatistiksel olarak önemsiz bulunmuştur (Çizelge 2). Ancak çiçeklenme süresi yıllara bağlı olarak önemli farklılık göstermiştir. Birinci yıl 224 günde çiçeklenme görülürken ikinci yıl çiçeklenmesi 10 gün daha geç gerçekleşmiştir. Ülkemizde yapılan yem bezelyesi çeşit tescil denemelerinde (Anon., 2016) çiçeklenme süresinin yıllara, çeşitlere ve lokasyonlara göre değişiklikler gösterdiğ belirlenmiştir. Çiçeklenme süresi bitkilerin erken veya geç olgunlaşmalarının bir göstergesidir. Erzurum gibi yüksek rakımlı yerlerde yetiştirilen bitkilerin erken veya geç çiçek açmaları önem taşır. Araştırmanın ilk yılında çiçeklenmeye ulaşma süresi daha kısa olmuştur. Bu durum ikinci yılın daha yağışlı geçmesinden kaynaklanmış olabilir. Özellikle bitkilerin aktif büyüme gerçekleștirdiği Mayıs ayı yaklaşık olarak 3 kat daha fazla yağış almıştır (Çizelge 1). Sayar (2007) da araştırmamıza benzer olarak yem bezelyesinde çiçeklenme süresinin uzamasını kış aylarının soğuk, ilkbahar aylarının daha yağışlı ve serin geçmesine bağlamıştır.

Araştırmada yem bezelyesi genotiplerinin kışı geçirme oranları Çizelge 3'te görülmektedir. Bu oran hem genotiplere hem de yıllara göre önemli değişim göstermiş, bunlara ait interaksiyon da önemli bulunmuştur. İnteraksiyon açısından ele alındığı zaman kışı geçirme oranı \%91.7-84.7 arasında olan uygulamalar birinci grubu oluşturmaktadırlar. Bunlar arasında birinci yıldaki Taşkent ve Töre çeşitleri (\%91.7 ve \%91.0) ile ikinci yıldaki Özkaynak çeşidi (\%90.1) ilk sıraları almışlardır. Seleksiyon ile geliştirilen hatlar arasında ilk yıldaki H-6, H-10, H13, H-14 ve H-15 ile ikinci yıldaki H-8'in değerleri de yüksek bulunmuştur. Elde edilen sonuçlar genotiplerin Erzurum şartlarında kış periyoduna dayanıklılıklarının bir göstergesidir. 
Çizelge 3. Yem bezelyesi genotiplerinin kışı geçirme oranı ve dal sayıları

\begin{tabular}{|c|c|c|c|c|c|c|}
\hline \multirow{2}{*}{ Genotipler } & \multicolumn{3}{|c|}{ K1ş1 Geçirme Oranı (\%) } & \multicolumn{3}{|c|}{ Dal Sayıs1 (adet/bitki) } \\
\hline & $2012-13$ & 2013-14 & Ortalama & $2012-13$ & 2013-14 & Ortalama \\
\hline Kirazlı & 77.0 & 77.7 & $77.3 \mathrm{~B}$ & 2.4 & 1.6 & $2.0 \mathrm{E}$ \\
\hline Özkaynak & 84.7 & 90.1 & $87.7 \mathrm{~A}$ & 3.1 & 3.0 & $3.0 \mathrm{~A}-\mathrm{D}$ \\
\hline Taşkent & 91.7 & 72.0 & $81.8 \mathrm{AB}$ & 2.5 & 3.7 & $3.1 \mathrm{ABC}$ \\
\hline Töre & 91.0 & 72.3 & $81.7 \mathrm{AB}$ & 2.3 & 2.4 & $2.4 \mathrm{CDE}$ \\
\hline Ürünlü & 86.0 & 72.3 & $79.2 \mathrm{AB}$ & 2.4 & 2.2 & $2.3 \mathrm{CD}$ \\
\hline $\mathrm{H}-5$ & 85.7 & 71.0 & $78.3 \mathrm{AB}$ & 2.1 & 3.1 & $2.6 \mathrm{CDE}$ \\
\hline H-6 & 87.3 & 60.0 & $73.7 \mathrm{BC}$ & 2.3 & 3.3 & $2.8 \mathrm{BCD}$ \\
\hline $\mathrm{H}-8$ & 66.0 & 87.3 & $76.7 \mathrm{BC}$ & 3.3 & 3.6 & $3.4 \mathrm{AB}$ \\
\hline $\mathrm{H}-10$ & 86.0 & 68.7 & $77.3 \mathrm{~B}$ & 2.4 & 2.4 & $2.4 \mathrm{CDE}$ \\
\hline $\mathrm{H}-13$ & 86.0 & 71.7 & $78.8 \mathrm{AB}$ & 2.6 & 3.0 & $2.8 \mathrm{BCD}$ \\
\hline $\mathrm{H}-14$ & 88.0 & 71.0 & $79.5 \mathrm{AB}$ & 2.5 & 2.5 & $2.5 \mathrm{CDE}$ \\
\hline $\mathrm{H}-15$ & 86.7 & 72.3 & $79.5 \mathrm{AB}$ & 2.3 & 2.4 & $2.4 \mathrm{CDE}$ \\
\hline H-17 & 72.7 & 62.7 & $67.7 \mathrm{C}$ & 3.1 & 4.3 & $3.7 \mathrm{~A}$ \\
\hline Ortalama & $83.7 \mathrm{~A}$ & $73.1 \mathrm{~B}$ & 78.4 & 2.6 & 2.9 & 2.8 \\
\hline $\begin{array}{l}\text { Önemlilik } \\
\text { LSD }\end{array}$ & Genotip** 9.4 & $\begin{array}{l}\text { Y1 } 1 * * \\
3.7\end{array}$ & $\begin{array}{l}\mathrm{G} \times \mathrm{Y} * * \\
13.2\end{array}$ & $\begin{array}{l}\text { Genotip** } \\
0.8\end{array}$ & $\begin{array}{l}\text { Y1l } \\
\text { ö.d. }\end{array}$ & $\begin{array}{l}\mathrm{G} \times \mathrm{X} * \\
0.8\end{array}$ \\
\hline
\end{tabular}

*: $0.05, * * ; 0.01$ düzeyinde önemlilik gösterir. Farklı harfle işaretlenmiş ortalamalar istatistiksel olarak birbirinden farklıdır. ö.d.: Önemli değil

$\mathrm{Bu}$ sonuçlar geliştirilmiş olan hatların bölgenin kış şartlarına uyumunun tescilli çeşitlerle yarışabilir, hatta bazılarından daha iyi düzeyde olduğunu göstermektedir. İkinci yılda genel olarak kışı geçirme oranları daha düşüktür. Bu durum muhtemelen kar örtüsünün olmadığı Aralık ayı sıcaklığının $\left(-13.8{ }^{\circ} \mathrm{C}\right)$ ikinci yılda daha düşük olmasından kaynaklanmaktadır. Bezelye için öldürücü düşük sicaklık derecesi -8.5 ${ }^{\circ} C^{\prime}$ 'dir (Murray vd., 1988). Ancak yeterli kar örtüsünün varlığında çok daha fazla düşük sıcaklıklara dayanabilir. Öldürücü soğukların olduğu döneme 4-5 yapraklı ve rozet formunda giren bezelye bitkileri soğuklardan en az seviyede etkilenmektedirler (Annicchiarico ve Iannucci, 2007; Alan ve Geren, 2012). Karaköy vd. (2016) de bezelye genotipleri arasında soğuğa dayanıklılık bakımından yüksek düzeyde farklılık olduğunu belirlemişler, yabancı orijinli çeşitlerin kışı atlatamadıklarını tespit etmişlerdir.

Bitki başına dal sayısı genotiplere göre farklılık gösterirken, yıla bağlı olarak önemli bir değişim görülmemiştir. Dal sayısı üzerinde genotip $\mathrm{x}$ y1l interaksiyonu önemli bulunmuştur (Çizelge 3). En yüksek dal sayısı (4.3 ve 3.7 adet) ikinci yılda $\mathrm{H}-17$ hattı ile Taşkent çeşidinde belirlenmiştir. Dallanma bitkilerde genetik bir özellik olup hat ve çeşitler arasında farklılık göstermesi beklenen bir durumdur. Genotiplerin yıllık iklim şartlarına bağlı olarak az veya çok gelişmeleri dallanmalarında farklılıklar oluşturabilmektedir. Tan vd. (2011) yerel yem bezelyesi çeşitlerinde dal sayısının genotiplere ve yıllara göre değişiklik gösterdiğini tespit etmişlerdir.

Bitkide bakla sayısı üzerinde sadece genotipler istatistiksel olarak önemli bulunmuştur (Çizelge 4). Taşkent çeşidi ve H-14 hattı en yüksek bakla sayısına sahip olurken, bunları H-5, Töre ve H-6 takip etmiştir. Kirazlı ise en düşük bakla sayısına sahip olmuştur. Bakla sayısı tohum verimi için önemlidir. Singh vd. (2011) ve Tan vd. (2012) bezelyede bakla sayıs ile tohum verimi arasında önemli ve olumlu bir ilişki belirlemişlerdir. Yapılan çalışmalarda yem bezelyesi hat veya çeşitlerinde bakla sayısının 5-15 adet arasında değiştiği belirlenmiştir (Timurağaoğlu vd., 2004; Sayar, 2007; Tan vd., 2012).

Bakladaki tane sayısında genotipler ve genotip $\mathrm{x}$ yıl interaksiyonu önemli bulunmuştur. Araştırmada H-5 hatt1 hem ilk y1lda hem de ikinci yilda baklasinda tohum sayısı (7.0 adet ve 8.2 adet) en fazla olan materyal olarak öne çıkmıştır (Çizelge 4). Baklada tohum sayısı en düşük olan materyal ise (4.0 adet) ikinci yılda H-8 hattı olmuştur. Tan vd. (2012) bu değerin yem bezelyesi genotiplerinde 3.5-5.6 adet arasında değiştiğini ve baklada tohum sayısı ile tohum veriminin negatif ilişkili olduğunu bildirmişlerdir. Alan ve Geren (2012) yem bezelyesinde bakladaki tane sayısının çeşitlere göre değiştiğini, Özköse (2017) ise yıl $x$ hat interaskiyonun önemli olduğunu bildirmişlerdir. 
Çizelge 4. Yem bezelyesi genotiplerinin bitkide bakla ve baklada tane sayıları

\begin{tabular}{|l|l|l|l|l|l|l|}
\hline \multirow{2}{*}{ Genotipler } & \multicolumn{3}{|c|}{ Bitkide Bakla Say1s1 (adet/bitki) } & \multicolumn{3}{c|}{ Baklada Tane Say1s1 (adet/bakla) } \\
\cline { 2 - 7 } & $2012-13$ & $2013-14$ & Ortalama & $2012-13$ & $2013-14$ & Ortalama \\
\hline Kirazl1 & 5.2 & 6.2 & $5.8 \mathrm{D}$ & 5.5 & 4.7 & $5.1 \mathrm{~B}$ \\
\hline Özkaynak & 8.9 & 9.1 & $9.0 \mathrm{BC}$ & 6.1 & 4.5 & $5.3 \mathrm{~B}$ \\
\hline Taşkent & 12.1 & 10.3 & $11.2 \mathrm{~A}$ & 5.7 & 3.9 & $4.8 \mathrm{C}$ \\
\hline Töre & 9.5 & 11.0 & $10.3 \mathrm{AB}$ & 5.6 & 5.9 & $5.8 \mathrm{~B}$ \\
\hline Ürünlü & 9.3 & 7.3 & $8.3 \mathrm{C}$ & 6.4 & 5.6 & $6.0 \mathrm{~B}$ \\
\hline H-5 & 10.9 & 9.7 & $10.3 \mathrm{AB}$ & 7.0 & 8.2 & $7.6 \mathrm{~A}$ \\
\hline H-6 & 9.6 & 9.2 & $9.4 \mathrm{ABC}$ & 5.5 & 6.5 & $6.0 \mathrm{~B}$ \\
\hline H-8 & 8.3 & 7.9 & $8.1 \mathrm{C}$ & 5.8 & 4.0 & $4.9 \mathrm{~B}$ \\
\hline H-10 & 9.2 & 8.9 & $9.1 \mathrm{BC}$ & 6.5 & 4.9 & $5.7 \mathrm{~B}$ \\
\hline H-13 & 8.9 & 8.9 & $8.9 \mathrm{BC}$ & 6.3 & 4.9 & $5.6 \mathrm{~B}$ \\
\hline H-14 & 10.6 & 11.5 & $11.0 \mathrm{~A}$ & 5.7 & 5.4 & $5.5 \mathrm{~B}$ \\
\hline H-15 & 8.3 & 9.9 & $8.9 \mathrm{BC}$ & 5.8 & 6.3 & $6.0 \mathrm{~B}$ \\
\hline H-17 & 9.2 & 8.9 & $8.9 \mathrm{BC}$ & 5.4 & 5.2 & $5.3 \mathrm{~B}$ \\
\hline Ortalama & 9.1 & 9.2 & 5.9 & 5.4 & 5.7 \\
\hline $\begin{array}{l}\text { Önemlilik } \\
\text { LSD }\end{array}$ & Genotip** 1.9 & Y1l & G x Y & Genotip** & Y1l & G x Y** \\
\hline
\end{tabular}

** 0.01 düzeyinde önemlilik gösterir. Farklı harfle işaretlenmiş ortalamalar istatistiksel olarak birbirinden farklıdır. ö.d.: Önemli değil

Araştırmada tohum verimleri hem genotiplere hem de yıllara bağlı olarak önemli değişim göstermiş, genotip x yıl interaksiyonu da önemli bulunmuştur (Çizelge 5). İki yıllık ortalamada 15 ve 10 numaralı hatlar sirasiyla $315.4 \mathrm{~kg} / \mathrm{da}$ ve 314.7 $\mathrm{kg} / \mathrm{da}$ verim ile ilk sıraları almışlardır. Araştırmanın ilk y1l verimleri ikinci yıla göre daha yüksek bulunmuştur. İnteraksiyon açısından ele alındığında ilk yılda $\mathrm{H}-15$ hattı en verimli materyal olmuş (407.8 $\mathrm{kg} / \mathrm{da}$ ), bunu H-10, H-5 ve H-6 hatları takip etmişlerdir $(362.7,348.8$ ve $344.0 \mathrm{~kg} / \mathrm{da})$. Bütün materyallerin verimleri ikinci yılda daha düşük olurken, Özkaynak ve H-13 ikinci yılda daha yüksek verim vermişlerdir. Materyaller arasında yıllara göre gerçekleşen bu farklılık interaksiyonun önemli çıkmasına neden olmuştur.

Çizelge 5. Yem bezelyesi genotiplerinin tohum verimleri ve hasat indeksleri

\begin{tabular}{|c|c|c|c|c|c|c|}
\hline \multirow{2}{*}{ Genotipler } & \multicolumn{3}{|c|}{ Tohum Verimi $(\mathrm{kg} / \mathrm{da})$} & \multicolumn{3}{|c|}{ Hasat İndeksi (\%) } \\
\hline & $2012-13$ & $2013-14$ & Ortalama & $2012-13$ & 2013-14 & Ortalama \\
\hline Kirazlı & 339.2 & 172.7 & $255.9 \mathrm{ABC}$ & 30.5 & 20.9 & $25.7 \mathrm{BCD}$ \\
\hline Özkaynak & 242.6 & 335.3 & $289.0 \mathrm{AB}$ & 29.7 & 36.7 & $33.2 \mathrm{AB}$ \\
\hline Taşkent & 270.6 & 247.3 & $259.0 \mathrm{ABC}$ & 38.9 & 32.6 & $35.7 \mathrm{~A}$ \\
\hline Töre & 227.2 & 165.7 & $196.5 \mathrm{C}$ & 26.2 & 25.8 & $26.0 \mathrm{BCD}$ \\
\hline Ürünlü & 326.3 & 199.0 & $262.7 \mathrm{ABC}$ & 29.6 & 12.4 & $21.0 \mathrm{D}$ \\
\hline H-5 & 348.8 & 119.0 & $233.9 \mathrm{ABC}$ & 23.1 & 19.0 & $21.0 \mathrm{D}$ \\
\hline $\mathrm{H}-6$ & 344.0 & 170.3 & $257.2 \mathrm{ABC}$ & 33.6 & 19.1 & $26.4 \mathrm{BCD}$ \\
\hline $\mathrm{H}-8$ & 304.5 & 153.3 & $228.9 \mathrm{ABC}$ & 27.9 & 15.0 & $21.4 \mathrm{D}$ \\
\hline $\mathrm{H}-10$ & 362.7 & 266.7 & $314.7 \mathrm{~A}$ & 34.7 & 28.5 & $31.6 \mathrm{ABC}$ \\
\hline $\mathrm{H}-13$ & 203.9 & 285.3 & 244.7 ABC & 24.1 & 25.2 & $24.7 \mathrm{BCD}$ \\
\hline $\mathrm{H}-14$ & 311.5 & 213.3 & $262.4 \mathrm{ABC}$ & 35.1 & 25.2 & $30.2 \mathrm{ABC}$ \\
\hline H-15 & 407.8 & 223.0 & $315.4 \mathrm{~A}$ & 36.4 & 18.8 & 27.6 A-D \\
\hline $\mathrm{H}-17$ & 307.0 & 107.7 & $207.3 \mathrm{~B}$ & 33.0 & 15.6 & $24.3 \mathrm{CD}$ \\
\hline Ortalama & $307.4 \mathrm{~A}$ & $204.5 \mathrm{~B}$ & 256.0 & $31.0 \mathrm{~A}$ & $22.7 \mathrm{~B}$ & 268.9 \\
\hline $\begin{array}{l}\text { Önemlilik } \\
\text { LSD }\end{array}$ & $\begin{array}{l}\text { Genotip** } \\
10.0\end{array}$ & Y11 **35.7 & $\mathrm{Gx} \mathrm{Y}^{* *} 128.6$ & $\begin{array}{l}\text { Genotip** } \\
8.6\end{array}$ & $\begin{array}{l}\mathrm{Y}_{1} 1^{* *} \\
3.4\end{array}$ & $\begin{array}{l}\mathrm{G} \times \mathrm{Y} * * \\
12.2\end{array}$ \\
\hline
\end{tabular}

** 0.01 düzeyinde önemlilik gösterir. Farklı harfle işaretlenmiş ortalamalar istatistiksel olarak birbirinden farklıdır.

Tohum verimleri kullanılan yem bezelyesi materyallerinin bölgeye uyumunun bir göstergesidir.
Mevcut şartlarda daha iyi gelişme gösteren bitkiler daha yüksek verimli olmaktadır. Bu durumda H-10 
ve H-15 numaralı hatların bölgeye uyumlu olduklarını söylemek mümkündür. Diğer taraftan seleksiyon ile geliştirilmiş olan bu hatların ülkemizde yaygın olarak kullanılan çeşitlerden daha verimli oldukları dikkat çekicidir. Yem bezelyesinde yapılan çalışmalar değişik bölgelerde çeşitlerin performanslarının değiştiğini ortaya koymaktadır (Uzun vd., 2012; Alan ve Geren, 2012; Kavut vd., 2016). Timurağaoğlu vd. (2004) Ankara kurak koşullarında tane yem veya tohumluk amaciyla P.57K ve P.101 nolu hatların yetiştirilmesini önermişlerdir. Açıkgöz vd. (2007) yem bezelyesinde genotip $\mathrm{x}$ çevre interaksiyonunun çok önemli olduğunu ve hasatta birim alandaki bitki sayısının tohum verimi üzerine doğrudan etkili olduğunu bildirmişlerdir. $\mathrm{Bu}$ çalışmada da genel olarak kışı geçirme oranı yüksek olan materyallerin tohum verimlerinin de yüksek olduğu görülmektedir. İkinci yılda tohum verimlerinin düşük bulunması, bu yılda karsız geçen Aralık ayının daha soğuk geçmesi ve kıştan çıkma oranlarının düşük olmasından kaynaklanabilir. Yillar arasındaki iklim farklılıklarının bezelyede tohum verimine önemli etkiler yaptığı diğer çalışmalarda da belirlenmiştir (Açıkgöz vd., 2007; Uzun vd., 2012; Alan ve Geren, 2012).

Hasat indeksi üzerine yine genotip ve yılların çok önemli etkisi olmuş, bunlara ait interaksiyon önemli çıkmıştır (Çizelge 5). İki yıllık ortalamada Taşkent çeşidi en yüksek hasat indeksine (\%35.7) sahip olmuştur. Bunu Özkaynak çeşidi takip etmiştir. Tohum verimi yüksek olan $\mathrm{H}-10, \mathrm{H}-14$ ve $\mathrm{H}-15$ hatlarının hasat indeksleri de yüksek olan gruba dahil olmuşlardır. Hasat indeksi yıllara bağlı olarak değişmiş, ikinci yılda daha düşük bulunmuştur. $\mathrm{Bu}$ durum ikinci yılda tohum verimlerindeki düşüklükten kaynaklanmıştır. Birinci yılda Taşkent (\%38.9), ikinci yılda ise Özkaynak (\%36.7) daha yüksek değere sahip olmuşlardır. Hasat indeksi bitkinin toplam üretiminde tohum üretiminin payını gösterir. $\mathrm{Bu}$ nedenle genel olarak tohum verimi yüksek olan materyallerin hasat indeksleri de yüksektir. Araştırmada Özkaynak ve Taşkent tohum verimleri ön sıralarda olan çeşitlerdir. Bunların yanında H-10, $\mathrm{H}-14$ ve $\mathrm{H}-15$ hatlarının tohum verimlerinin yüksek olması hasat indeksinde de üst siralarda olmalarını sağlamıştır. Değişik yem bezelyesi hat ve çeşitlerini inceleyen çalışmalarda hasat indeksini Uzun vd. (2005) \%15.1-24.8, Sayar vd. (2009) \%0.8-51.5 ve Tan vd. (2012) \%27.5-33.6 arasında belirlemişlerdir. Sayar ve Anlarsal (2008) seleksiyon ile geliştirilen bazı hatların çeşitlerden daha yüksek hasat indeksine sahip olduğunu bulmuşlardır.

\section{SONUÇ}

Doğu Anadolu Bölgesi ve Erzurum ilinde kış dönemi oldukça uzun ve soğuk geçmektedir. Bu bölgede kışlık olarak yetiştirilecek tek yıllık baklagil yem bitkisi türü kısıtlıdır. Yem bezelyesi gibi değerli bir yem bitkisinin bu şartlarda kışlık olarak yetişebilmesi büyük bir avantajdır. Bu araştırma ülkemizde tescil edilmiş çeşitlerden Töre hariç, diğerlerinin mevcut şartlarda tohum verimlerinin yüksek olduğunu ortaya koymuştur. Bunun yanında özellikle $\mathrm{H}-10$ ve $\mathrm{H}-15$ nolu hatlar başta olmak üzere diğer hatların da (H-17 hariç) bölgede tohum üretimi için uygun oldukları ortaya çıkmıştır. $\mathrm{H}-10$ ve $\mathrm{H}-15$ nolu hatların tescil edilmek üzere değerlendirilmeleri uygun gözükmektedir.

\section{TEŞEKKÜR}

$\mathrm{Bu}$ araştırma TAGEM/TBAD/12/A03/P01/005 nolu proje ile desteklenmiştir.

\section{KAYNAKLAR}

Açıkgöz, E., 2001. Yem Bitkileri. Uludağ Üniv. Güçlendirme Vakfi Yay No: 182. Bursa.

Açıgöz, E., Üstün, A., Gül, İ., Anlarsal, A. E., Tekeli, A. S., Nizam, İ., Avcioğlu, R., Geren, H., Çakmakçı, S., Aydınoğlu, B., Yücel, C., Avcı, M., Acar, Z., Ayan, I., Uzun, A., Bilgili, U., Sincik M., Yavuz, M., 2007. Yem bezelyesi (Pisum sativum L.)'nde genotip $\mathrm{x}$ çevre ilişkileri ve kuru madde ile tohum veriminde stabilite analizleri, Türkiye 7.Tarla Bitkileri Kong., Erzurum, s: 79-82.

Alan, Ö., Geren, H., 2012. Bezelyede (Pisum sativum L.) farklı ekim zamanlarının tane verimi ve diğer bazı tarımsal özellikler üzerine etkisi. Ege Üniv. Ziraat Fak. Derg., 49: 127-134.

Annicchiarico, P., Iannucii, A., 2007. Winter survival of pea, faba bean and white lupin cultivars in contrasting Italian locations and sowing times, and implications for selection. Journal of Agricultural Science, 145: 611-622.

Anonim, 2016. Yem Bezelyesi Tescil Raporu. Gida Tarım ve Hayvancılık Bakanlığı Tohumluk Tescil ve Sertifikasyon Merkez Müdürlüğü, Ankara, 2016.

Ayaşan, T., 2010. Ruminant ve kanatlı beslenmesinde bezelye kullanımı. Süleyman Demirel Üniversitesi Ziraat Fakültesi Dergisi 5 (2):74-82.

Bilgili, U., A. Uzun, M. Sincik, M. Yavuz, B. Aydınoğlu, S. Cakmakçı, H. Geren, R. Avcıoglu, İ. Nizam, A.S. Tekeli, İ. Gül, E. Anlarsal, C. Yücel, M. Avcı, Z. Acar, İ. Ayan, A. Üstün, E. Açıkgöz, 2010. Forage yield and lodging traits in peas (Pisum sativum L.) with different leaf types. Turkish Journal of Field Crops, 15(1): 50-53.

Çil A., 2007. Harran ovası koșullarında bazı bezelye (Pisum sativum $\mathrm{L}$.) hatlarını ot ve tane verimlerinin saptanmasi. Türkiye VII. Tarla Bitkileri Kong., 25-29 Haziran 2007, Erzurum.

Geren, H., Alan Ö., 2012. Farklı ekim zamanlarının iki bezelye (Pisum sativum L.) çeşidinde ot verimi ve diğer bazı özellikler üzerine etkileri. Anadolu Derg., 22(2): 37-47.

Kadıŏlu, S., 2011. Fosforlu Gübre ve Fosfor Çözücü Bakteri Uygulamasının İki Farklı Yem Bezelyesi Çeşidinde Verim ve Verim Unsurlarına Etkisi. Atatürk Üniv. Fen Bilimleri Enstitüsü, Doktora Tezi, Erzurum.

Karaköy, T., Demirbaş, A., Yörük, V., Toklu, F., Bolach, F.S., Ton, A., Anlarsal, A.E., Özkan, H., 2016. Sivas ekolojik koşullarında soğuğa dayanıklı bezelye (Pisum sativum ssp. sativum L. ve ssp. arvense L.) genotiplerinin belirlenmesi. Tarla Bitkileri Merkez Araştırma Enstitüsü Derg., 25 (Özel say1-1): 171-176.

Kavut, Y.T., Çelen, A. E., Çıbık, Ş.E., Urtekin, M. A., 2016. Ege 
Bölgesi koşullarında farklı sıra arası mesafelerinde yetiștirilen bazı yem bezelyesi (Pisum arvense L.) çeșitlerinin verim ve diğer bazı özellikleri üzerine bir araştırma. Tarla Bitkileri Merkez Araştırma Enstitüsü Derg., 25 (Özel say1-2): 225-229.

Kaya, İ., Yalçın, S., 1999. Baklagil tane yemleri ve ruminant rasyonlarında kullanımı. Lalahan Hayvancılık Araştırma Enstitüsü Derg., 39 (1): 101-114.

Masoero, F., Moschini M., Fusconi, G. and Piva, G. 2006. Raw, Extruded and Expanded Pea (Pisum sativum) in Dairy Cows Diets. Italian Journal of Animal Sci., 5 (3), 237247.

Murray, G.A., Eser, D., Gusta, L.V., Eteve, G., 1988. Winterhardiness in pea, lentil, faba bean and chickpea. Cool Season Food Legumes, 5: 831-843.

Özköse, A., 2017. Farklı ekim derinliklerinin yem bezelyesinin verim ve bazı verim özellikleri üzerine etkileri. Sakarya Üniversitesi Fen Bilimleri Enstitüsü Derg., 21(6): 11881200 .

Sayar, M.S., 2007. Diyarbakır Ekolojik Koşullarında Bazı Yem Bezelyesi (Pisum arvense L.) Hat ve Çeşitlerinin Verim ve Verim Öğelerinin Belirlenmesi Üzerine Bir Araştırma. Yüksek Lisans Tezi, Çukurova Üniv. Fen Bilimleri Enst., Adana.

Sayar, M.S., Anlarsal, A.E., 2008. A research on determination of yield and some yield components of forage pea (Pisum arvense L.) cultivars and lines in Diyarbakır ecological conditions. Ç.Ü. Fen Bilimleri Enstitüsü Derg., 17(4): 7887.

Sayar, M. S., Anlarsal, A.E., Başbağ, M., Gül, İ., Açıkgöz, E., 2009. diyarbakır koşullarında bazı yem bezelyesi (Pisum arvense L.) hatlarının verim ve verim unsurlarının belirlenmesi. Türkiye VIII. Tarla Bitkileri Kong., 19-22 Ekim 2009, Hatay.

Singh, A., Singh, S., Prasad Babu, J.D., 2011. Heritability, character association and path analysis studies in early segregating population of field pea (Pisum sativum L. var. arvense) Int. J. Plant Breed. and Gen., 5: 86-92.

Tan, M., Koç, A., Elkoca, E., 2011. Doğu Anadolu'nun Bazı İllerinde Yetiștirilen Yem Bezelyesi Populasyonlarından Ot ve Tohum Tipi Hatların Geliştirilmesi. TÜBITTAKTOVAG 1070134 Nolu Proje Sonuç Raporu.
Tan, M., 2018. Baklagil ve Buğdaygil Yem Bitkileri. Atatürk Üniv. Ziraat Fak. Ders Yayınları No: 190, Erzurum, 286 s.

Tan, M., Koç, A., Dumlu Gul, Z., 2012. Morphological characteristics and seed yield of East Anatolian local forage pea (Pisum sativum ssp. arvense L.) ecotypes. Turkish Journal of Field Crops. 17(1): 24-30.

Tan, M., Koç, A., Dumlu Gül, Z., Elkoca, E., Gül, I., 2013. Determination of dry matter yield and yield component of local forage pea (Pisum sativum ssp. arvense L.) ecotypes. Tarım Bilimleri Derg., 19: 289-296.

Tekeli, A.S., Ateş, E., 2003. Yield and its components in field pea (Pisum arvense L.) lines. Journal of Central European Agriculture, 4(4): 312-318.

Tamkoç, A., 2007. Kıșlık olarak ekilen yem bezelyesi hatlarının verim ve bazı bitkisel özellikleri, Türkiye VII. Tarla Bitkileri Kongresi, 25-27 Haziran, Cilt 2, s: 94-97, Erzurum, 2007.

Timurağaoğlu K.A., Genç A., Altınok S., 2004. Ankara koşullarında yem bezelyesi hatlarında yem ve tane verimleri. Tarım Bilimleri Derg., 10(4): 457-461.

Tosun, F., 1974. Baklagil ve Buğdaygil Yem Bitkileri Kültürü. Atatürk Üniv. Yayın No:242, Ziraat Fak. Yayın No: 123. Ders Kitapları Serisi No:8, Erzurum.

TÜİK, 2017. www.tuik.gov.tr (Erişim tarihi: 28.02.2018).

Uzun, A., 1997. Değişik Yaprak Formlarına Sahip Yem Bezelyesi Çeşitlerinde Ekim Zamanı ve Ekim Sıklığının Verim ve Verim Öğelerine Etkisi. Doktora Tezi, Uludağ Üniv. Fen Bilimleri Enstitüsü, Bursa.

Uzun A., Bilgili, U., Sincik, M., Filya I., Acikgoz, E., 2005. Yield and quality of forage type pea lines of contrasting leaf types. European Journal and Agronomy, 22: 85-94.

Uzun, A., Gün, H., Açıkgöz, E., 2012. Farklı gelişme dönemlerinde biçilen bazı yem bezelyesi (Pisum sativum L.) çeşitlerinin ot, tohum ve ham protein verimlerinin belirlenmesi. Uludağ Üniv. Ziraat Fak. Derg., 26(1): 2738.

Volpelli, L.A., Comellini, M., Masoero, F., Moschini, M., Lo Fiego, D.P., Scipioni, R., 2009. Pea (Pisum sativum) in dairy cow diet: Effect on milk production and quality. Italian Journal of Animal Sci., 8 (2): 245-257. 